\title{
Features of the prevention of intentional homicide by criminal police units
}

\section{Особливості профілактики умисних вбивств підрозділами кримінальної поліції}

Received: March 10, 2021

\begin{abstract}
The purpose of the article is to characterize the features of prevention of intentional homicide in terms of its implementation by criminal police units. Subject of research: The subject of research is the prevention of intentional homicide by criminal police units. Methodology: epistemological and legal method, methods of generalization and analysis, method of grouping, statistical, documentary and social survey methods, logical method are used in the course of the research. The results of the research: The article considers the main problems of determining the place and role of the victim in intentional encroachments on human life. Typical situations that lead to encroachment on life are analyzed, the role of the victim in each specific situation is determined. Practical implications: The main preventive measures to prevent intentional homicide by the police in general and criminal police units in particular are identified. Value / originality: The exceptional importance of intentional homicide preventing under modern conditions is substantiated.
\end{abstract}

Accepted: April 7, 2021

\author{
Written by: \\ Khyzhniak Yevhen ${ }^{75}$ \\ https://orcid.org/0000-0001-8263-0353 \\ Khankevych Andrii ${ }^{76}$ \\ https://orcid.org/0000-0002-6897-347X \\ Shapovalenko Yevhen ${ }^{77}$ \\ https://orcid.org/0000-0001-7973-686X \\ Shkelebei Viktoriia ${ }^{78}$ \\ https://orcid.org/0000-0002-2717-097X \\ Yatsyk Tetiana ${ }^{79}$ \\ https://orcid.org/0000-0003-0664-7115
}

\begin{abstract}
Анотація
Метою статті є характеристика особливостей профілактики умисним посяганням на життя людини в аспекті здійснення іiі підрозділами кримінальної поліції. Предмет дослідження: Предметом дослідження $є$ профілактика умисних посягань на життя людини підрозділами кримінальної поліції. Методологія: діалектичний метод, метод аналізу та синтезу, логіко-семантичний метод, системний метод, метод класифікації та групування, індуктивний метод. Результати дослідження: У статті розглядаються основні проблеми визначення місця й ролі жертви в умисних посяганнях на життя людини. Аналізуються типові і ситуації, які призводять до посягання на життя, визначається роль жертви в кожній конкретній ситуації. Практичні наслідки: Визначені основні профілактичні заходи з попередження умисних вбивств поліцією загалом та підрозділами кримінальної поліції зокрема. Цінність / оригінальність: Обгруновується виключне значення профілактики умисних посягань на життя людини в сучасних умовах.
\end{abstract}

\footnotetext{
${ }^{75} \mathrm{Ph} . \mathrm{D}$. in Law, Associate Professor of the Department of Criminalistics of the National University "Odessa Law Academy", Ukraine. ${ }^{76} \mathrm{Ph}$.D. in Law, Associate Professor. Professor of the Department of Investigative Activities and Crime Investigation of Kharkiv National University of Internal Affairs, Kharkiv, Ukraine.

${ }^{77} \mathrm{Ph} . \mathrm{D}$ in Law, Associate Professor, Associate Professor of the Department of Investigative Activities of the National Academy of Internal Affairs, Ukraine.

${ }^{78} \mathrm{PhD}$ in Law, Associate Professor, Associate Professor of the Department of Criminal Law and Procedure of the National University of Kyiv-Mohyla Academy, Ukraine.

${ }^{79} \mathrm{PhD}$ in Law, Associate Professor, Professor of the Department of Financial Investigation of the University of the State Fiscal Service of Ukraine, Ukraine.
} 
Key Words: prevention, intentional homicide, police, criminal police units.

\section{Introduction}

The direct duty of the criminal police is to ensure the principle of inevitability of punishment for violent crimes and other illegal acts provided by the norms of the criminal law with double prevention (threat of murder, harm to health, assault, torture), as well as those that establish liability for illegal acquisition, transfer, sale, storage, transportation or carrying of weapons, ammunition, explosives or explosive devices, etc. and certain administrative offenses (petty hooliganism, shooting in settlements and maladjusted areas or in violation of the established procedure, drinking alcohol in public places or appearing in public in a state of intoxication, etc. This allows to achieve a preventive effect in the fight against assault on a person (Shevchenko \& Nykyforchuk, 2015).

The tasks facing criminal police units in preventing violent crimes are the same for all units and follow from the general tasks of crime prevention. However, the degree of participation of each service or unit, the forms and methods of their work are different depending on the competence. At the same time, they complement each other, enriching the preventive activity with various elements and turning it into a coherent system.

The urgency of the study is due to the great importance of solving the problems of cessation of intentional homicide in Ukraine. There has been an increase in crime in general and in serious crimes against the person (such as intentional homicide) in particular in recent years. Thus, the number of registered homicides in Ukraine has increased by almost $10 \%$ over the last 10 years. Most of them are committed in Kyiv, Kharkiv, Donetsk and Odessa regions (Shevchenko \& Nykyforchuk, 2015).

\section{Methodology}

The methodological basis for the research is philosophical, modern general and special methods of scientific knowledge. Their application is due to a systematic approach, which allows to analyze the problems in terms of their social content and legal form. In particular: with the help of the epistemological and legal method the activity of the criminal police units on intentional homicide prevention is thoroughly
Ключові слова: профілактика, умисні вбивства, поліція, підрозділи кримінальної поліції.

considered. On the basis of the methods of generalization and analysis the main problems of determining the place and role of the victim in intentional encroachments on human life are identified. The method of grouping is used for identifying the main stages of investigative prevention, as well as for determining traditional categories of persons who, due to objective and subjective circumstances, are subject to special control by law enforcement agencies. Statistical, documentary and social survey methods are applied to determine the categories of persons who commit violent crimes, including intentional homicide. Logical method helps to make relevant conclusions.

\section{Literature Review}

Theory of prevention of crimes by police units was formed in the late 60's - early 70's of the $20^{\text {th }}$ century. It was then that in the works of many researchers there was a stable scientific position that crime prevention is a system of economic, socio-cultural, educational and legal measures taken by government agencies, public organizations to combat crime and eliminate its causes. Thus, in the 60 's of the $20^{\text {th }}$ century Herbert Pecker (1998) concluded that there are two models to combat crime - Due Process Model (priority is given to the protection of the individual's rights) and Crime Control Model (priority is given to controlling crime by restricting the rights of the individual).

Moore, Trojanowicz, and Kelling (1988, p. 4) considering the features of preventing crimes by police state that some key reasons that lead to committing serious offences are irrelevant to police officers as they do not fall under the scope of their powers (e.g., difficult economic situation, poor schooling, psychological diseases or disorders). According to the authors, 4 precipitating causes of crime seem relevant to policing: (1) dangerous people; (2) criminogenic situations; (3) alcohol and drug use; and (4) frustrating relationships.

Sherman, Gottfredson, MacKenzie, Eck, Reuter, and Bushway (1998, p. 2) claim that the main efforts of the police units, i.e. criminal ones, when preventing serious offences should be focus on: “(a) reductions in delinquency, juvenile 
crime, youth gang activity, youth substance abuse, and other high-risk factors; (b) reductions in the risk factors in the community, schools, and family environments that contribute to juvenile violence; and (c) increases in the protective factors that reduce the likelihood of delinquency and criminal behavior."

Long (2019) proves that targeted arrests is the best means to prevent serious crimes. To achieve this aim criminal police units should cooperate with patrol police and specialists in crime prevention and jointly develop effective arrest strategies.

The problem of preventing of such serious crime as corruption was considered by Shcherbakovskyi, Stepaniuk, Kikinchuk, Oderiy, Svyrydova, (2020, p. 118). The scholars state that the fight against corruption in Ukraine is one of the main tasks of law enforcement agencies and preventing such violations requires strict adherence to the general requirements for conducting undercover activities (which are implemented by criminal police units), formulated in the decisions of the European Court of Human Rights and domestic courts.

In the former USSR, scientific research in this area was limited to the work of such Russian scientists as Aleksieiev and Sinilov (1978, p. 166), who in the late 1970s suggested that operational units, using covert methods, also carry out preventive measures, which to some extent do not correspond to the traditional organizational and tactical forms of police activities of law enforcement agencies.

The first attempt to theoretically substantiate the prevention of crimes by criminal police units by applying the operational and search activities was made in the work by Ovchinsky (1982, p. 45). Analyzing this work, it can be argued that it has updated the theoretical development of crime prevention problems by law enforcement agencies that implement police operations.

\section{Results and Discussion}

The share of violent crimes for personal gain has increased. The so-called "commissioned crimes", in particular murders, have become widespread in recent years. Crimes of this category are mainly committed by adults $(26-50$ years), whose share in the structure of domestic violence is $73.5 \%$. At the same time, $36-45$ years is the most criminogenic age group, which committed two-fifths $(39.7 \%)$ of these crimes.
It is followed by two groups of $26-30$ years and $46-50$ years $(13.2 \%$ of crimes). In every tenth case of domestic violence $(10.3 \%)$ criminals are the persons from 51 to 60 years old, and in $7.4 \%$ of cases they are even older. Very rarely $(0.7 \%)$ this crime is committed by minors.

Assassination is one of the most dangerous and very lucrative areas of criminal activity, which should be distinguished from assassinations committed on domestic grounds. Leading scientists and law enforcement specialists distinguish two groups of assassinations: domestic murders and business murders (both legal and criminal), and it is difficult to disagree. The crimes of the first group clearly exceed the crimes of the second group, and are about $85 \%$. The effectiveness of their disclosure is quite high - on average about $90 \%$.

The analysis of assassinations shows that victims were killed near their places of residence (usually when leaving and entering) in $50-60 \%$ of cases; far less frequently - at the victims' places of work. Quite often the victims are killed on the way to work or residence.

The means of murder used to commit these crimes are quite diverse. The choice of tool mainly depends on the purpose of the offense. If its purpose is to exert psychological influence on the victim's environment, then combat firearms and explosive devices are usually applied. If the purpose of the murder is other one ("silent murder"), then the arsenal of means is much broader: from poison, and radioactive substances to various cold steel weapons, and other devices (Vasylevych, 2016).

Unfortunately, there is no reduction in these crimes. This is due to the growing professionalism and organization of criminal activities, the use of corrupt connections by criminals in the preparation, commission and concealment of murders. The number of these crimes committed with firearms, explosives and substances is increasing.

The motive for assassinations committed by an organized criminal group is profit. Quite often it is expressed in the elimination of competitors in the business areas, both legal and criminal (the struggle for influence in the market of illegal goods and services). Sometimes this motive can be combined with other ones, such as, for example, revenge.

Persons who have committed murders are generally characterized by low level of spiritual 
development, the dominance of basic needs. Most of them are sociopaths: anti-social in nature, emotionally stupid, incapable of compassion.

As practice shows, criminals are more frequently masking intentional homicide under the disappearance of citizens. A significant number of such cases are related to the activities of organized criminal groups, as a result of which entrepreneurs, bankers, commercial workers, children, the elderly, homeowners and owners of vehicles with the latter, are increasingly disappearing. As Romashkin (2020, p. 537) correctly note, for more than five decades, enforced disappearance has been a sign of state terror and proof of lack of justice. According to this horrible practice, a person can be arrested or stolen and then no further information about her whereabouts is known. All the traces of the victim were deliberately destroyed: there is neither a missing note, nor information or body. Relatives and society as a whole receive psychological trauma and material damage, and criminals can stay unpunished.

Nowadays, more than 10000 people are being sought in Ukraine, 4500 of which are being sought in the course of investigative activities, and the rest ones - by investigation and tracking records. The current situation not only does not meet social expectations, but also provokes a negative public reaction to the activities of law enforcement agencies and officials, whose duty is to search for missing persons and effectively investigate the facts of such disappearances (Pavlenko, Sevruk, Ishchuk 2015, p. 252).

Legal nihilism and low level of education of the major part of the population of our State lead to an increase in such crimes as intentional homicide. The goal of crime prevention is achieved by improving material security, raising cultural level and awareness of citizens. The organization of the prevention of intentional homicide requires the application of knowledge of management, law and special sciences. To perform the tasks of combating crime, it is also necessary to use scientific advances in improving the forms and methods of investigative activities, obtained from the study of materials of operational practice.

According to the Constitution of Ukraine (Law No. 254k/96-VR, 1996) law enforcement agencies are called upon to address issues related to the protection of the individual and ensuring the observance of the rights and freedoms of citizens. Thus, "the human being, his or her life and health, honour and dignity, inviolability and security are recognised in Ukraine as the highest social value" states Article 3 of the Constitution of Ukraine. "Every person has the inalienable right to life. No one shall be arbitrarily deprived of life. The duty of the State is to protect human life. Everyone has the right to protect his or her life and health, the lives and health of other persons against unlawful encroachments" (Article 27 of the Constitution of Ukraine). The practice of combating law enforcement agencies against crimes that encroach on human life indicates that their timely detection and prevention is possible only if the criminal police officers are properly aware of the specifics of their elimination.

There are three levels of intentional homicide prevention in modern science:

1) solving important social, economic and other problems of society, which provides indirect systematic influence on all levels of anti-social behavior;

2) the impact on specific social groups in which negative phenomena occur. Here it is necessary to promptly eliminate various shortcomings identified in the life of the team (social group);

3) individual preventive work, i.e. positive change in the system of value orientations of the individuals, whose behavior deserves special attention (Sniherov 2005, p. 73).

It should be noted that investigative measures include the collection of information about the planned intentional homicides, the behavior of specific individuals, the causes of certain crimes that require preventive activity. Such actions are carried out by the means of the following operative and search actions: aimed at the disintegration of the groups formed for commission of premeditated murders, reassignment of its participants, separation of some persons from the environment that negatively affects their behavior. We share the opinion of Ovchinsky (1982, p. 5) that the theoretical foundations of operational and investigative prevention were formed simultaneously with the theory of operational and investigative information. In fact, prevention provided for and was based on informationanalytical and information-prognostic maintenance of police operations. 
We also agree with Khaliliev (2012, p. 567) that investigative prevention can be divided into three stages, namely:

1) operative and search prevention of intentional homicides (both general, and individual ones). Its essence consists in elimination, neutralization of causes and conditions (objective and subjective), circumstances and factors (internal and external) in relation to the possible offender.

2) Operative and search prevention of offences. It is aimed at identification of persons whose actions could be considered as illegal intention to commit a crime or may turn into a crime.

3) Cessation of crimes using the possibilities of investigative activities. It occurs in case of failure to solve the problem of crime prevention in the first two stages.

General prevention measures, which can ensure a consistent reduction in intentional homicide, can be divided into two interrelated and interdependent groups:

- preventive measures carried out by public authorities and local self-government, as well as other management by virtue of its competence, which can affect the negative phenomena that occur (by responding to relevant appeals and documents, or on their own initiative);

- preventive measures carried out directly by criminal police units.

There are traditional categories of persons who, due to objective and subjective circumstances, are subject to special control by law enforcement agencies, namely:

- persons previously convicted of intentional homicide;

- previously convicted of violent crimes;

- persons who that have not been corrected after serving their sentences and who were in places of imprisonment;

- persons who abuse alcohol;

- drug addicts;

- persons who do not have a specific place of residence and occupation;

- family offenders;

- mentally ill with aggressive behavior and other categories of persons.

Preventive measures are aimed at those prone to committing offenses, their immediate environment, criminogenic groups and other sources of destabilization of the criminogenic situation at the local level. We are talking about helping young people to obtain legal sources of income, combating trafficking in drug and weapons, rehabilitation and social support of drug and alcohol addicts, obstructing the sale of criminally acquired property, conducting outreach and educational work with the public, monitoring the lifestyle of persons included in the operational and preventive records, filling and use of retrieval systems. Emphasis is placed on the expediency of applying "double preventive measures", as well as identifying and terminating the activities of mercenary criminal groups, eliminating opportunities for committing crimes, searching for persons suspected of committing mercenary and violent crimes and bringing them to justice.

Therefore, intentional homicide prevention is the implementation of measures to establish and eliminate the causes of this type of crime and the conditions that contribute to their commission. Sources of information about intentional homicide that is planned or being prepared can be statements of citizens and officials, members of the public, undercover officers, and other operational information obtained from the analysis of the operational situation and statistics.

When the operations officer receives such information, he (she) should find out what exactly are the reasons and conditions that led to this situation. It has been said, that there have been qualitative and quantitative changes in the causes and conditions that contribute to the commission of intentional homicide due to the changes in social, economic, political and cultural relations in the country. The success of their prevention, first of all, depends on daily and purposeful work of operational services in this direction.

Thus, the main measures to prevent intentional homicide (i.e. by criminal police units) are the following:

- timely response to various violations of public order and, above all, to those that encroach on the lives and health of citizens;

- conducting joint raids with the public on the most criminogenic objects;

- encouragement of citizens who provide assistance to law enforcement agencies;

- intensification of activities to identify persons who illegally keep firearms; establishing the ways to purchase or manufacture it;

- strengthening supervision of previously convicted persons; establishing control over 
their lifestyle and sources of material support; getting involved in solving their problems;

- $\quad$ increase the efficiency of operational work to prevent intentional homicide;

- timely disclosure and quality investigation of intentional homicide criminal cases;

- elimination of shortcomings and mistakes made in the work of operational units;

- wider use of special tools used in operational and investigative activities;

- study and implementation of the achievements of other States aimed at preventing intentional homicide;

- removal from the streets and prosecution of drunks, beggars and prostitutes; studying their lifestyle and taking more effective preventive measures against these categories of people;

- $\quad$ establishing and taking measures against the holders of dens;

- close cooperation with operations officers specializing in the area against drug trafficking and organized criminal groups;

- maintaining contact with supervisors at the place of work of the person under control;

- co-operation with medical institutions in exchanging information of interest in the fight against intentional homicide;

- making speeches of police officers of different levels on television and radio broadcasts to promote a healthy lifestyle and prevent offenses;

- organization of such performances in labor collectives and educational institutions;

- ensuring law and order during mass events, on-site court hearings, when cases of intentional homicide and other high-profile crimes are being considered;

- participation in the allocation of resources of the National Police of Ukraine, taking into account the operational situation in the region;

- taking measures to separate groups with anti-social orientation;

- urgent verification of complaints and signals about the threat of intentional homicide;

- ensuring conspiracy in work; taking measures that exclude the possibility of leakage of operational information, encouraging those who provide assistance in the fight against crime, etc.;

- prevention of other types of crimes that can also lead to death of a person.

\section{Conclusion}

Summing up, it is worth noting that prevention, both in its general form and in cases of intentional encroachment on human life is a powerful means that allows to achieve positive changes, make a real impact on crime, prevent a significant number of dangerous and imminent attacks in a short time. At the same time, our research shows that today the main problem with the application of preventive measures of this nature is not that the actors who carry them out are not interested and motivated to implement such activities, but the victims themselves are not only unaware of their situation, but also in explaining their situation they are blatantly unwilling to change it. Prevention of intentional homicide as the main direction in the fight against this type of crime should not be limited to identifying the causes of these offences and their elimination, but also involves measures such as creating an atmosphere of intolerance to violations of norms and rules of public life, involving population in the fight against crime, the imposition of fair punishment for the crime, the proper organization of its serving. Thus, the implementation of preventive measures in the practice of criminal police units will undoubtedly contribute positively to the fight against intentional homicide. State - legal mechanisms should guarantee the safety of every participant in society, because the safety of the individual depends on the mutual social well-being, which determines the main task of the law enforcement system.

\section{References}

Aleksieiev, A. (1978). Operational and preventive monitoring. Moskow: All-Russian Research Institute of the Ministry of Internal Affairs of the USSR.

Khaliliev, R. (2012). Forms of investigative activities and problems of their classification. Scientific Bulletin of Dnipropetrovsk State University of Internal Affairs, Num. 4, pp. 555-561. Available online. http://nbuv.gov.ua/UJRN/Nvdduvs_2012_4_82. Consultation date: 09/03/2021.

Law of Ukraine No. 254k/96-VR. The Constitution of Ukraine of June 28, 1996. Available online. https://zakon.rada.gov.ua/laws/show/254\%D0\% BA/96-\%D0\%B2\%D1\%80\#Text. Consultation date: 09/03/2021.

Long, R. (2019). Crime Prevention Through Targeted Arrest Strategies. Police Chief Online. Available online. 
https://www.policechiefmagazine.org/crimeprevention-through-targeted-arrest-strategies/. Consultation date: 09/03/2021.

Moore, M., Trojanowicz, R. and Kelling, G. (1988). Crime and Policing. National Institute of Justice, Num. 2. Available online. https://www.ojp.gov/pdffiles1/nij/111460.pdf.

Consultation date: 09/03/2021.

Ovchinsky, S. (1982). Operational and preventive prevention. Karaganda: Karaganda Higher School of the Ministry of Internal Affairs of the USSR.

Packer, H. (1998) Two Model of the Criminal Process. USA: Stanford University Press.

Pavlenko, S., Sevruk, V., \& Ishchuk, D. (2015). Investigation of murders related to the disappearance of a person: problematic issues and areas for improvement. Available online. http://elar.naiau.kiev.ua/bitstream/123456789/8 $163 / 1 / \% \mathrm{~d} 0 \% 9 \mathrm{f} \% \mathrm{~d} 0 \% \mathrm{a} 0 \% \mathrm{~d} 0 \% 90 \% \mathrm{~d} 0 \% 92 \% \mathrm{~d} 0$ $\% 9 \mathrm{e} \% \mathrm{~d} 0 \% 92 \% \mathrm{~d} 0 \% 86 \% 20 \% \mathrm{~d} 0 \% \mathrm{a} 0 \% \mathrm{~d} 0 \% 95 \%$ d0\%a4\%d0\%9e\%d0\%a0\%d0\%9c\%d0\%98\%20 $\%$ d0\%a7\%201_p255-257.pdf. Consultation date: 09/03/2021.

Romashkin, S. (2020). Historical background and key elements of crime accordingly to International Convention for the Protection of all Persons from Enforced Disappearance. Amazonia Investiga, Vol. 9(28), pp. 536-544. https://doi.org/10.34069/AI/2020.28.04.58 https://amazoniainvestiga.info/index.php/amazo nia/article/view/1350/1210

Shcherbakovskyi, M., Stepaniuk, R., Kikinchuk, V., Oderiy, O., and Svyrydova, L. (2020). Evidentiary problems in the investigation of corruption crimes in Ukraine. Amazonia
Investiga, Vol. 9(32), pp. 117-124. https://doi.org/10.34069/AI/2020.32.08.12

https://amazoniainvestiga.info/index.php/amazo nia/article/view/1481/1425

Sherman, L., Gottfredson, D., Mackenzie, D., Eck, J., Reuter, P. and Bushway, S. (1998). Preventing Crime: What Works, What Doesn't, What's Promising. National Institute of Justice. Research in Brief. Available online. https://www.ojp.gov/pdffiles/171676.pdf.

Consultation date: 09/03/2021.

ShevchenkO, O. and Nykyforchuk, D. (2015). Investigative prevention of intentional homicide in Ukraine. Available online. http://elar.naiau.kiev.ua/bitstream/123456789/7 019/1/\%2B\%20\%D0\%90\%D0\%9A\%D0\%A2\% D0\%A3\%D0\%90\%D0\%9B\%D0\%AC\%D0\%9 D\%D0\%86\%20\%D0\%9F\%D0\%A0\%D0\%9E\% D0\%91\%D0\%9B\%D0\%95\%D0\%9C\%D0\%98 $\% 20 \% \mathrm{D} 0 \% 92 \% \mathrm{D} 0 \% 94 \% \mathrm{D} 0 \% 9 \mathrm{E} \% \mathrm{D} 0 \% \mathrm{~A} 1 \% \mathrm{D}$ 0\%9A\%D0\%9E\%D0\%9D\%D0\%90\%D0\%9B\% D0\%95\%D0\%9D\%D0\%9D\%D0\%AF\%20\%D0 $\%$ A72_p203-207.pdf. Consultation date: 09/03/2021.

Sniherov, O. (2005). Prevention of intentional homicide. Forum Prava, Num. 1, pp. 70-77. Available online. In: http://www.nbuv.gov.ua/ejournals/FP/2005-1/05soppuv.pdf. Consultation date: 09/03/2021.

Vasylevych, V. and others (2016). Multimedia Training Manual "Criminological Victimology" (Theme 8 "Criminological victimology of nonprofit violent crimes"). Available online. https://arm.naiau.kiev.ua/books/kryminoloh_vik tym/pluginAppObj_14_02/t6.pdf. Consultation date: 09/03/2021. 